\title{
Situating Ontario's Colleges between the American and European Models for Providing Opportunity for the Attainment of Baccalaureate Degrees in Applied Fields of Study
}

\author{
Michael L. Skolnik \\ University of Toronto
}

\begin{abstract}
During the last third of the twentieth century, college sectors in many countries took on the role of expanding opportunities for baccalaureate degree attainment in applied fields of study. In many European countries, colleges came to constitute a parallel higher education sector that offered degree programs of an applied nature in contrast to the more academically oriented programs of the traditional university sector. Other jurisdictions, including some Canadian ones, followed the American approach, in which colleges facilitate degree attainment for students in occupational programs through transfer arrangements with universities. This article offers some possible reasons why the Ontario Government has chosen not to fully embrace the European model, even though the original vision for Ontario's colleges was closer to that model to than to the American one.
\end{abstract}

\section{Résumé}

$\mathrm{Au}$ cours du dernier tiers du $2 \mathrm{O}^{\mathrm{e}}$ siècle, les réseaux collégiaux de nombreux pays se sont donné comme mission d'accroître les occasions d'obtention de baccalauréat dans des domaines d'études appliquées. Dans de nombreux pays d'Europe, les collèges ont progressivement constitué un secteur parallèle d'enseignement supérieur offrant des programmes d'études appliquées 
menant à un grade, à l'inverse du secteur universitaire traditionnel, lequel favorise plutôt les études théoriques. Dans d'autres juridictions, dont certaines au Canada, on a plutôt suivi le modèle américain selon lequel les collèges facilitent l'obtention de grades dans des programmes axés sur les professions par le biais d'ententes de transfert avec les universités. Le présent article propose certaines raisons susceptibles d'expliquer pourquoi le gouvernement de l'Ontario a choisi de ne pas adopter entièrement le modèle européen, malgré le fait que la vision initiale des collèges de l'Ontario se rapprochait davantage de ce dernier que du modèle américain.

\section{Introduction}

During the last third of the twentieth century, one of the principal ways in which many countries increased access to postsecondary education was by establishing new sectors of institutions that were intended to provide an alternative to traditional universities. The primary mission of these institutions was to prepare graduates for jobs and careers. Besides their focus on preparation for employment, other characteristics that differentiated the newer sectors were emphasis on teaching; use of pedagogies that emphasized experiential and hands-on learning; limited involvement in research; and admission of students from a wide range of socioeconomic and educational backgrounds, including secondary school vocational streams. The new sectors were created by merging existing vocational institutions and by adding new institutions.

In the early 1970s, analysts at the OECD reported that the new sectors fit one of three patterns: the multipurpose model, the specialized model, and the binary model (OECD, 1971; OECD, 1973). The prototype for the multipurpose model was the American junior college. Its defining characteristics were a "fairly close" link with the university, and diversified curricula that included purely academic programs, various types of general education, and vocational training of a "terminal nature" (OECD, 1973, p. 15). The main locations of this model were said to be the United States, some western provinces of Canada, and Québec.

In the specialized model, the institutions provided vocational training of a terminal nature largely for students from the non-academic streams of the secondary schools. Most of the institutions specialized in one or a few fields of study, and links with universities were "loose or almost nonexistent" (OECD, 1973, p. 16). Almost all the countries of continental Europe were said to fit this pattern, but it was noted that some had introduced reforms that could lead to significant changes.

In the binary model, the newer sector was independent of the universities and offered its own degree programs that had an applied orientation. It was noted that among OECD countries, the binary model was found almost exclusively in the United Kingdom, but it was suggested that this model might be emerging in Ontario.

As the new sectors continued to evolve after the early 1970s, the specialized model largely ceased to exist, leaving two principal models that were similar but not identical to the other two original models. Most specialized non-university postsecondary institutions have been amalgamated into comprehensive institutions, and the few that remain exist alongside comprehensive institutions rather than in a sector that is composed of specialized institutions. 
What the OECD called the binary model has become the predominant model for the non-university sector in Europe, where these institutions offer a wide range of baccalaureate and, in some countries, postgraduate degree programs and constitute a parallel degree-granting sector to the universities. The term "binary" is no longer appropriate when describing this model because that term has often been used in a more generic manner simply to denote the existence of two distinct sectors of postsecondary education, regardless of their relationship with each other. What was originally known as the binary model could now be described more accurately as a parallel model, because degree granting is a major function of each sector, or it could be called the European Model because of its predominance in Europe.

In the multipurpose model, the institutions in the non-university sector do not normally award any baccalaureate degrees although, as will be discussed later, recently in some jurisdictions some of these institutions have been allowed to award a limited number of baccalaureate degrees. In this model, the principal-and until recently, only-avenue for students who complete an associate degree, diploma, or certificate in the nonuniversity sector and wish to attain a baccalaureate degree is to transfer to an institution in the university sector and complete a baccalaureate degree there. Since students take lower level undergraduate courses in one sector and upper level courses in the other sector, the relationship between sectors could be described as vertical. As the United States provides the oldest and largest example of the vertical model, this model could also be called the American Model.

This article examines the evolution of Ontario's colleges in relation to the European and American models and how opportunities for students in career and technical fields is provided in order to allow them to continue their education to the level of the baccalaureate degree. It is noted that while Ontario's colleges started out closer to the European than to the American model, they subsequently adopted features of both models and now represent a hybrid of the two models. The major question posed in the article is why, after being closer to the European model in their early years, Ontario's colleges have not more fully embraced it.

The next section elaborates on the differences between these two models, particularly with respect to their development. It suggests that baccalaureate degree attainment may be problematic for jurisdictions like Ontario where a large proportion of students begin postsecondary education in career-focused institutions that offer few or no baccalaureate programs.

The third section of the article describes how the role of Ontario colleges in facilitating baccalaureate degree attainment has evolved over the years and is followed by a section that offers some possible reasons why Ontario colleges have not more fully embraced the European model. Besides addressing questions about the organization of postsecondary education in Ontario and Canada, it is hoped that the article may contribute to the study of comparative higher education by comparing the roles that non-university postsecondary institutions play in facilitating baccalaureate degree attainment in different countries.

Before elaborating on these two models, the author's personal biases should be noted. Having conducted research on the role of Ontario colleges in facilitating degree attainment for more than 25 years, I have formed some opinions on the subject. Perhaps the most important one is that it is both beneficial for learners and more efficient for society if colleges play a more substantial role in facilitating degree attainment than was envisaged 
for them at the time of their founding. Acting on this belief, I have at times been an advocate for improved transfer arrangements and for the awarding of baccalaureate degrees by colleges. Much of my research in this area has been funded by research grants, for example from the Social Sciences and Humanities Research Council of Canada, or from my own resources. However, other research projects have been undertaken as a consultant to various agencies, such as the former Council of Regents for the Colleges of Applied Arts and Technology, the College-University Consortium Council, and most recently, Colleges Ontario. Finally, I should note that since discovering the European model in the late 1980 , I have felt that it has not received the attention in Canada that it merits, and one of the purposes of writing this article is to give more visibility to that model.

\section{Development of the Two Models}

Non-university postsecondary institutions in Europe evolved from vocational institutions, many dating back to the $19^{\text {th }}$ century, and had their roots in guilds (Huisman, 2008). Although originally the newer institutions were not considered part of higher education (Taylor, Ferreira, Machado, \& Santiago, 2008), in several European countries the new system of comprehensive vocational institutions was molded into a parallel sector of degree-granting institutions. The transformation of these institutions into predominantly degree-granting institutions occurred at different times during the last four decades of the $20^{\text {th }}$ century, beginning with the United Kingdom in the 1960 s.

Because of the applied orientation of the technical colleges in Europe, their degrees were perceived to be different from those awarded by the universities. For example, in recognition of this perceived difference, originally the degrees awarded by fachhochschulen in Germany had to include the notation "FHS" to indicate the type of institution from which the degree was earned, but later that requirement was abolished (Klumpp \& Teichler, 2008). A similar requirement existed originally in Ontario: degrees awarded by colleges had to include the word "applied" in their title. The colleges sought to do away with this requirement because they felt that it might adversely affect student interest in their degree programs (Colleges Ontario, 2009)-even though their marketing efforts often drew attention to the applied nature of their programs. The requirement was eliminated in 2009.

The precise nature of an applied degree and how it differs from a conventional academic degree has not been well articulated (Skolnik, 2013), and while these degrees may be attractive to some employers, many universities in Europe have been reluctant to admit graduates of applied degree programs to master's programs, a situation that exists also in Ontario (R.A. Malatest \& Associates, 2010). The difficulty that graduates of their baccalaureate programs had getting into university master's programs is one the factors that led the hogescholen in the Netherlands to introduce their own master's programs (Witte, van der Wende, \& Huisman, 2008). In the European countries that have adopted the parallel model, there are no systemic arrangements for transfer from technical colleges into baccalaureate programs in universities.

The principal motivations for establishing the newer sectors of institutions that offer career-focused degree programs were (1) to provide a less costly way of expanding higher education than simply expanding traditional universities, (2) to produce graduates whose knowledge and skills would meet emerging needs of industry and contribute to 
economic growth, and (3) to expand access to higher education and increase degree attainment by bringing in many individuals from groups that had been under-represented in traditional universities. Also, in many European countries, having a parallel system of degree-granting institutions with an applied focus served to extend to the postsecondary level the academic-vocational streaming that existed in the schools. This opened degree opportunities to students who had been streamed away from the university admission pathway in secondary school (Slantcheva-Durst, 2010).

Applied sectors of higher education in many European countries have come to account for substantial proportions-in some cases, the majority-of baccalaureate enrolment. These sectors enroll about $66 \%$ of baccalaureate degree students in the Netherlands and about 33\% in Germany (Klumpp, de Boer, \& Vossensteyn, 2014), about 60\% in Finland (Ministry of Education and Culture, 2009), and 48\% in Ireland (Higher Education Authority of Ireland, 2013). Institutions in the non-university sector in these countries offer programs in a range of regulated professional and other applied fields, such as law and engineering in some countries. They also offer programs in fields that would be recognizable in Ontario colleges: safety and security management, international hospitality, materials processing technology, sports and health promotion, community sports leadership, information technology, web development and creative media, and transport management. The baccalaureate programs in these institutions are normally three or four years duration.

The use of the vertical model for the production of baccalaureate degrees in career and technical fields is a relatively recent phenomenon in the history of the community college. Offering transfer programs in academic fields was the raison d'être of the junior college; however, until the late $20^{\text {th }}$ century, the vocational programs of community colleges were thought of as "terminal education" (Brint \& Karabel, 1989; Townsend, 2002). This was the way that occupational programs were viewed at the time Ontario's colleges of applied arts and technology were established, and since all the colleges' programs were intended to be in occupational fields (rather than in the liberal arts and sciences), there was no reason to make any provision for college-to-university transfer in the original plan for the colleges (Skolnik, 2010).

By the late 1980 s the notion was gaining currency that community college career programs should not necessarily be treated as terminal. It was suggested that advances in knowledge and technology had made the baccalaureate degree a desirable, or even necessary, qualification in several career programs the colleges were offering (Walker \& Floyd, 2005; Townsend, Bragg, \& Ruud, 2009). A concern voiced at a conference organized by the Ontario Minister of Colleges and Universities in 1988 was that the lack of opportunities for students in college career programs to further advance their education was impeding the development of the skills and knowledge that were needed by employers (Stoll, 1993).

The goal of facilitating baccalaureate degree attainment for students in community college career programs could have been achieved by extending associate degree programs in applied fields to the level of the baccalaureate degree. However, given the history and identification of community colleges as transfer institutions, an alternative strategy was adopted. This strategy was to bring to career education similar processes and infrastructure that had been developed earlier to enable students taking a two-year program in liberal arts and sciences to transfer to a university. 
Because Ontario colleges did not originate as junior colleges, it had not been necessary for them to develop the transfer infrastructure that colleges in many American states and a few Canadian provinces had developed for their arts and sciences transfer function. Thus, Ontario's colleges were not building upon their own experience and infrastructure when they initiated efforts to develop transfer arrangements to enable their students in career programs to transfer to universities. Rather, they were emulating colleges in the United States, British Columbia, and Alberta. Prior to these transfer initiatives, colleges and universities in Ontario had co-existed as two solitudes (Lewington, 1992).

American colleges found that although the extension of the transfer infrastructure to career education may have been natural for institutions already in the business of transfer, it was also problematic, due to the inherent differences between a liberal education and a career education (Townsend, 2004). While the curriculum of academic programs in two-year institutions had been designed expressly for the purpose of facilitating transfer to a four-year institution, this was not the case for career education programs. These had been designed to prepare graduates for the workforce, and their curriculum tended not to mesh with the curriculum of four-year institutions (Baker, 2002). One problem was that many of the courses in college career programs are specific to occupations for which fouryear institutions do not offer corresponding programs and therefore have no counterpart in their curricula. Moreover, having already taken many specialized courses in a two-year program, the would-be transfer student is attempting a move that conflicts with the normal university curriculum paradigm of starting with more general courses and narrowing the focus of study to more specialized courses as the student progresses through four years of study (Townsend, 2004).

In spite of efforts to overcome the problems of curriculum fit, such as those described by Townsend, Bragg, and Ruud (2008) and Ruud, Bragg, and Townsend (2010), transfer pathways for students who complete career programs in two-year institutions "are less than efficient" (Karandjeff \& Schiorring, 2011, p. 42). Bragg notes that attempts to establish sequential curricula that would facilitate efficient transfer between two- and fouryear institutions for students who seek to complete a baccalaureate program of an applied nature "meet with strong resistance" (Bragg, 2002, p. 30).

While the definitions and methodologies for measuring transfer rates vary enormously, it is generally found that transfer rates differ greatly between academic and career programs. For example, Townsend reported transfer rates for associate degree graduates in arts and sciences during the late 1990 os in Missouri, Oregon, Texas, and Washington ranged between $36 \%$ and $55 \%$, compared to rates for graduates of applied associate degree programs that ranged between $5 \%$ and $11 \%$ (Townsend, 2002). In part, these differences may reflect differences between the two groups in the strength of their desire to proceed to a baccalaureate degree. However, students in career programs also have more difficulty than those in academic programs in finding university programs that have an affinity with the fields of their associate degree program and in obtaining transfer credit for their college courses.

Comparable transfer rates to those found by Townsend have been reported for British Columbia in 2003: 41\% for arts and sciences and 8\% for applied programs. Transfer rates for applied programs in Alberta in 2002-2003 were 6.2\% (ACAATO, 2005). The same ACAATO study reported a 5.6\% transfer rate for applied programs in Ontario col- 
leges in 2003-2004 (ACAATO, 2005). The reason why Ontario's overall transfer rate is so much lower than the rates for British Columbia, Alberta, and most American states is because almost all of Ontario's enrolment is in career programs, rather than because its transfer rate in career programs is so much lower than that of other jurisdictions. A 2010 study published by the Higher Education Quality Council of Ontario (HEQCO) gives the overall college-to-university transfer rate in Ontario as about 5.5\% for 2007-2008 and 2008-2009 (Kerr, McCoy, \& Shuping, 2010). Trick (2013) cites some other Ontario studies that show transfer rates of $7 \%-8 \%$. The consensus of recent research is that the college-to-university transfer rate for Ontario is in the range of $5 \%-8 \%$.

Ontario's low overall college-to-university transfer rate, combined with the fact that about half the students who enter postsecondary education in Ontario begin in a college (Ontario Ministry of Training, Colleges and Universities, 2014a; 2014b), severely limits its rate of baccalaureate degree attainment. If we assume, for argument's sake, that the completion rate in career programs in Ontario colleges is $50 \%$, that the transfer rate for those graduates rate is $6 \%$, and that the rate of baccalaureate degree completion for those who transfer to university is $50 \%$, then of 1,000 students who enroll in a college, only 15 would obtain a baccalaureate degree.

Concern about the rate of baccalaureate attainment has been instrumental in leading many American states and Canadian provinces to give colleges the authority to award baccalaureate degrees. However, the scale of this activity is rather small. As of 2013 in the United States, 57 community colleges in 18 states had received approval to award baccalaureate degrees (Russell 2013). In Canada, six provinces and one territory now have some provision for colleges to award baccalaureate degrees (Weinrib \& Jones, 2014), but only a small number of colleges offer more than a few baccalaureate programs. College baccalaureate programs in Ontario account for less than $2 \%$ of full-time equivalent enrolment in baccalaureate programs in the province (Council of Ontario Universities, 2014; Panacci, 2014).

\section{Role of Ontario's Colleges in Facilitating Baccalaureate Degree Attainment in Applied Fields of Study}

In several ways the original vision for Ontario's colleges was closer to the parallel model developed in a number of European countries than it was to the vertical model developed in the United States. In introducing the legislation for the formation of Ontario's colleges, the Minister of Education stressed that there were to be "real differences" between these colleges and colleges in the United States, including the explicit rejection of the transfer function for Ontario's colleges (Davis, 1965, p. 12). Ontario colleges were to concentrate on career education and to offer three-year programs, which differentiated them from colleges in western Canada and the United States. This gave them a parallel feature with the universities, given how common three-year baccalaureate degrees in the universities were at the time the colleges were established.

In the early years of the colleges, the ministry emphasized that while the colleges were to be different from the universities, there should be "parity of esteem" between the two sectors (Campbell, 1975, p. 65). Baker suggested that three-year programs were developed in the colleges in order to "underline the commitment to parity of esteem" (Baker, 2002, p. 12). Parity of esteem between sectors was a plausible goal in principle for systems that 
had the parallel model, although ultimately the fact that only one of the two sectors was allowed to award degrees worked against parity of esteem. No pretense of parity of esteem was made in systems that employed the vertical model, since a hierarchical relationship between sectors was a defining feature of that model.

The idea that the establishment of the college system could be the harbinger of the parallel model was suggested by the recommendation of the Commission on Postsecondary Education in Ontario in 1972 that the colleges be allowed to award baccalaureate degrees to students who successfully completed their three-year programs (Commission on Postsecondary Education in Ontario, 1972). The rationale for this recommendation was to recognize that the effort required to complete a three-year program in a college was comparable to the effort required in a three-year university program, and to support parity of esteem between sectors.

It was not until 28 years after the Commission's recommendation that the government allowed the colleges to award baccalaureate degrees, and that was done in a way that would severely limit the scale of degree granting by the colleges. First, the government imposed limits on the extent of degree granting by colleges, $5 \%$ of total activity for most colleges, $15 \%$ in the case of the five colleges awarded the status of an Institute of Technology and Advanced Studies (Ontario Ministry of Training, Colleges and Universities, 2003). Second was the imposition of a lengthy and arduous quality assessment process that arguably was designed more for academically oriented than for applied-degree programs. Third was the decision by the government not to provide any significant amount of additional funding for college degree programs. Colleges receive only a slightly greater amount of funding for a baccalaureate degree program than for a diploma program ( Laden, 2005; R.A. Malatest \& Associates Ltd., 2010).

Not only were the conditions of and restrictions on college degree granting, pursuant to the 2000 legislation, indicative of at most a tepid adoption by the government of the European model, but the circumstances of the legislation suggested the government might have preferred the American model to the European model. In contrast to Alberta, where the government made clear that the primary purpose of allowing colleges to award degrees was to provide skills needed by industry (Government of Alberta, 1998), the remarks of the Ontario Minister, when introducing the legislation, suggested the emphasis in Ontario was to expand access to the baccalaureate degree (Cunningham, 2000). There was no statement in the documentation surrounding the Ontario legislation that was comparable to the statement of the Alberta Minister of Advanced Education that the new college degrees were intended to "provide valuable, practical learning opportunities for Albertans in skill areas where industry requires advanced career or technical preparation" (Government of Alberta, 1998, p. 1). The Ontario minister did not cite barriers to transfer as one of the factors that had led the government to introduce the Postsecondary Education Choice and Excellence Act, 2000. However, one probable motivation for the act may have been the lack of progress in the decade after Vision 2000 (Council of Regents for the Colleges of Applied Arts and Technology of Ontario, 1990), a report that reviewed the mandate of Ontario's colleges and called for improvements in opportunities for transfer (Skolnik, 2009). Indeed, the difficulties in obtaining satisfactory transfer arrangements had been identified by the colleges as one of the reasons for its recommendation to the government in 1998 that colleges be allowed to award baccalaureate degrees (ACAATO, 1998). 
Subsequent to the 2000 legislation, no significant move was made by the government to reduce the barriers that prevented expansion of degree granting by the colleges. In fact, at the time of writing this article, the government has not responded to recommendations it received from Colleges Ontario that are aimed at reducing some of those barriers (Colleges Ontario, 2012). No significant boost has been given to college degree granting (and thus to movement toward the European Model) since 2000; however, significant support has been given to transfer (i.e., movement toward the American Model) by the creation of the Ontario Council on Admission and Transfer (ONCAT) in 2011. The establishment of ONCAT was part of a major initiative, involving an investment of \$74 million, to improve transfer and student mobility in Ontario postsecondary education (ONCAT, 2014).

There is not necessarily a conflict between improving the opportunities for career education students in colleges to transfer to university and expanding baccalaureate granting by colleges. Indeed, the websites of the two colleges in the United States and Canada that offer the largest numbers of baccalaureate programs, St. Petersburg College in Florida and Humber College in Ontario, show that these institutions also provide extensive transfer arrangements for their students (Hicks, Weingarten, Jonker, \& Shuping, 2013; Humber College, 2015; St. Petersburg College, 2015a; 2015b). However, for students in the vast majority of colleges in Canada and the United States, transferring to a university is the principal, or only, means to obtaining a baccalaureate degree. Moreover, in jurisdictions in which colleges account for a substantial proportion of baccalaureate degrees, the opportunities to transfer from a college to a university in order to complete a degree (though not needed as much as in jurisdictions where colleges award few if any degrees) are limited to non-existent.

Given that rejection of the American model was such a noteworthy feature of the original plan for the colleges, and that in their early years the colleges were perceived by OECD to be closer to the European than to the American model, the next section explores the question of why Ontario has not embraced the European model.

\section{Why Ontario Has Not Embraced the European Model}

In the countries where a substantial proportion of baccalaureate degrees are awarded by institutions in an applied sector, this state of affairs came about largely as the result of government policy and usually as part of an overall plan for the postsecondary system, rather than as the cumulative effect of decisions of individual institutions (Taylor et al. 2008).

Since successive political parties that have formed Ontario governments have been averse to planning for the postsecondary sector (Royce, 1998; Jones, 2004 Clark, Moran, Skolnik, \& Trick, 2009), any major reform that needs to be part of an overall plan for the system has not been and is unlikely to be introduced-irrespective of the specific nature of the reform. The absence of system planning is an important factor in this context, because the rationale for the adoption of the parallel model in Europe was that it provided an economical and efficient structure for increasing the extent of awarding baccalaureate degrees, while still allowing universities to concentrate on their traditional intellectual and research functions. However, beyond noting that the non-adoption of the European model could simply be a result of the reluctance to undertake system planning for postsecondary education in Ontario, it might be of interest to speculate on factors that may have worked against this particular reform. 
The following are five possible reasons Ontario has not adopted the European model.

First, it is noteworthy that in the jurisdictions that have adopted the European model, the decision to do so was almost always made at the national level. Even in Germany, a country with a federated governance structure, decisions of the individual Länder (states) about the role of the fachhochschule were made within the national Framework Act for Higher Education and closely coordinated with one another (Klumpp \& Teichler, 2008). The only exception is the Flanders region of Belgium, where the applied programs of the hogescholen account for more than half of all new entrants to baccalaureate study. However, Flanders comprises $57.7 \%$ of Belgium's population (Portal Belgium Government, 2015) and has substantial autonomy in the provision of postsecondary education (Huys, Debackere, \& De Kock, 2009). It also coordinates with the Netherlands in many aspects of higher education, such as quality assurance.

It is a more complex challenge for a single province in a large country (on a large continent) to make such a change in its postsecondary system than for a whole country to do so, particularly when many neighbouring countries are also making the same change, as has been the case in Europe. Had Ontario adopted the European model in, say, the 1970s or 1980 s, there may have been concern at the time about how the degrees awarded by non-university sector institutions would be received, not only in Ontario but elsewhere in Canada and the United States. It was perhaps because of this concern that Ontario did not allow its colleges to award baccalaureate degrees until after British Columbia, Alberta, and several American states had already done so.

Second, the proximity of jurisdictions that employed the American model and the lack of proximity of jurisdictions that employed the European model likely made the former model more prominent than the latter, in the minds of government policy makers. It is difficult to know just how much awareness officials in the Ontario Government or key opinion leaders in the province had of the European model. Perhaps there were internal documents in the ministry that discussed the European model, but if so, these did not make the light of day.

So far as I can determine, the first public document to discuss the possible applicability of the European model in Ontario was the report on "advanced education" that I produced in 1989 for the Vision 2000 review of the mandate of the colleges (Skolnik, 1989). There does not appear to have been another public report on the European model in Ontario until nearly two decades later when the Higher Education Quality Council of Ontario commissioned three reports that addressed this subject (Doern, 2008; Jones \& Skolnik, 2009; Higher Education Strategy Associates, 2012).

A third possible explanation for not having embraced the European model lies in the comprehensiveness of Ontario's colleges, which were established during a period when consolidation of small entities such as school boards was in fashion. As a consequence, most forms of publicly supported adult education, developmental education, and shortterm training were brought together in colleges, perhaps limiting the attention and resources that could be devoted to baccalaureate programs. Most of the countries that adopted the parallel model did not have to confront this issue because the institutions that constituted the applied degree-granting sector had never become as comprehensive as the Ontario colleges had. Applied sector institutions in Finland, Germany, and the Netherlands "provide almost entirely advanced programmes of three years or more" (OECD, 
2005, p. 24). These countries tend to have three distinct tertiary sectors. For example, the Netherlands has 13 universities, 41 colleges of applied education, and 70 VET (vocational education and training) institutions that are responsible for upper secondary and adult vocational education and training (Klumpp et al. 2014; Netherlands Association of VET Colleges, 2014).

Fear that "lower skilled" activities would receive less attention if colleges were allowed to offer even a limited number of baccalaureate programs has been one of the major reasons why some have opposed the idea of the colleges awarding baccalaureate degrees. However, the experience of British Columbia colleges suggests this fear may be exaggerated. In a study of three community colleges that became university-colleges, Fleming and Lee (2009) found that, as the number of degree programs in these institutions increased, enrolment in apprenticeship, adult basic education, and other non-degree vocational programs remained stable or increased. Nevertheless, the colleges' dependence on the revenue and political support these kinds of programs provide could have made it difficult for them to move in a direction that may be perceived as placing these programs in jeopardy.

The fourth factor that might have impeded movement toward the European Model relates to the attitudes of postsecondary institutions. As noted earlier, it was not until 1998 that the association that represented the colleges came out in favour of the colleges being given the authority to award degrees (ACAATO, 1998). Focus groups conducted during the Vision 2000 review of the mandate of the colleges indicated that just a decade earlier the attitude of the colleges toward collaboration with universities in degree programs was somewhat ambivalent (McFayden, 1989). More vigorous advocacy by Colleges Ontario for expansion of degree granting, including its proposal to replace the colleges' three-year diploma programs with three-year baccalaureate programs did not begin until 2012 (Colleges Ontario, 2012; 2013).

While it might be assumed that universities everywhere would oppose a move to empower other types of postsecondary institutions to award baccalaureate degrees, it is impossible to draw firm conclusions because of the lack of systematic analysis of the positions that universities have taken on the matter. Witte et al. (2008) report that in Europe opposition from universities was the norm, but "the degree of resistance and the capability to express it varied" (Witte et al. 2008, p. 228). They report that university opposition to the fachhochschulen in Germany was weak, while the opposition of the universities to similar reforms in the Netherlands was more pronounced. Välimaa and Neovonen-Rauhala (2008) report that in most cases Finnish universities opposed the polytechnics being given degree-granting authority, but that the resistance was not "systematic or sharply defined" (Välimaa \& Neovonen-Rauhala, 2008, p. 80).

The first time Ontario universities were asked about the idea of the colleges awarding degrees was during the Vision 2000 consultations in 1989. University sector respondents tended to identify technical obstacles and to express concern that this might distract colleges from their traditional mission, rather than showing outright opposition to the idea (McFayden, 1989). It was not until the legislative committee hearings on the Postsecondary Education Choice and Excellence Act, 2000, that the university sector had to take a formal position on this question.

In his remarks to the legislative committee, the president of the Council of Ontario Universities, Dr. Ian Clark, did not object per se to colleges awarding degrees. The focus 
of his remarks was on the standards and processes for assuring the quality of college degrees (Standing Committee on General Government, 2000). The provincial association of university faculty did not take a position on allowing colleges to award baccalaureate degrees, but its brief to the legislative committee seemed to provide tacit acceptance of the idea (Ontario Confederation of University Faculty Associations, 2000). Of course, it is important to point out that what the universities were being asked about in these hearings was a proposal to allow colleges to apply on a case-by-case basis for the opportunity to offer degree programs in particular, applied areas of study, not necessarily for the colleges to become a parallel degree-granting sector, awarding a substantial proportion of the baccalaureate degrees in the province.

The fifth possible factor impeding the adoption of the European model in Ontario has been the difficulty of conceptualizing the quality of degrees awarded by newer types of postsecondary institutions in a manner other than conformity to the characteristics of the institutions that until the last third of the $20^{\text {th }}$ century had been the only ones to award degrees, that is, traditional universities. Trow suggested that during the evolution from elite to mass higher education, "the criteria against which new forms of mass higher education are assessed are typically those of the older, costlier forms of elite higher education" (Trow, 1973, p. 35). He expressed concern that because of this tendency, quality assurance processes could impede the development of new forms of higher education, such as the more practice-oriented degrees that applied sector institutions aim to award.

This type of concern about quality did not prevent many European countries from relying on applied sector institutions for a substantial portion of enrolment in baccalaureate degree programs, because the development of the parallel model in those countries occurred prior to the introduction of the kind of quality assurance systems that are so common now. For example, quality assessment of the programs of the hogescholen in the Netherlands did not begin until 1990, well after their development as degree-granting institutions (Centre for Higher Education Policy Studies, 2007). Perhaps because the awarding of degrees in the applied sector was so well established in Europe when qualityassurance systems were introduced, these systems had to accommodate to that reality. Thus, in many cases quality assurance frameworks in Europe included some provisions for differentiating between the applied programs of the colleges and the more academically oriented programs of the universities, for example, having different statements of expected learning outcomes for the two sectors or different criteria for assessing faculty qualifications (Skolnik, 2016). Moreover, since one of the purposes of the European model was to create degree attainment opportunities for people with academic backgrounds who had previously been inadmissible to or underserved by universities, admission requirements in applied sector institutions in European jurisdictions are different from those of universities.

By the time Ontario's colleges sought to award baccalaureate degrees, quality was already a major preoccupation, and quality assurance for baccalaureate programs of the colleges became the responsibility of a new agency, the Postsecondary Education Quality Assessment Board ${ }^{1}$ (PEQAB). Initially, the board developed distinct degree-level standards for baccalaureate degrees with an applied focus (Baker, 2002), but later it adopted the present approach of having a single set of degree-level standards that both college and university programs must meet (Postsecondary Education Quality Assessment Board, 
2014). The colleges have alleged that one of the factors impeding the expansion of degree programming in the college sector is that the PEQAB "uses a university degree model that is not designed for career-specific post-secondary programs" (Colleges Ontario 2013 p. 9). A committee that conducted an external review of the PEQAB reported hearing concerns from the colleges that "existing standards are over-weighted toward the academic culture of research universities, particularly in defining requirements for faculty" (Crow, Marsden, \& Rubidge, 2011, p. 18). While evaluating the validity of these college sector criticisms of PEQAB requirements for colleges is beyond the scope of this article, it is noteworthy that neither the degree-level standard nor the standards for admission requirements or faculty qualifications in PEQAB's Handbook for Colleges (Postsecondary Education Quality Assessment Board, 2014) differentiate between the applied programs of the colleges and the programs of the universities.

\section{Concluding Remarks}

The original plan for Ontario's college system was quite revolutionary in its day in providing a stand-alone alternative to the universities for career-focused postsecondary education. Over the next 35 years, however, as colleges in many other countries that originally had similar profiles as Ontario's colleges became largely degree-granting institutions, Ontario's colleges continued to concentrate on certificate and diploma programs. The growth of enrolment in these programs has resulted in Ontario having a very high percentage of the population with a sub-baccalaureate postsecondary credential compared to other jurisdictions, while having a middling ranking compared to other industrialized jurisdictions in regard to baccalaureate degree attainment. ${ }^{2}$ Relying more on the colleges for the production of baccalaureate degrees could have other benefits besides just increasing Ontario's rate of baccalaureate attainment. It could enable many residents of the province-especially those who have a particular penchant for hands-on learning-to develop their potential further than they might otherwise be able to do, and it could provide more people with the kind of advanced knowledge and skills needed to keep Ontario internationally competitive.

However, even if the Netherlands' approach of relying on colleges for over $60 \%$ of its baccalaureate degrees could be shown to be more efficient than the Ontario approach of relying on colleges for about $2 \%$ of its baccalaureate degrees, the transition costs of moving from the present structure to the European model-which should include providing at least modestly more funding for college degree programs than they currently receivecould be a major deterrent to transforming the system. That is to say, the best time to have adopted the European model would have been before the creation of a system that relies on 21 universities for the production of baccalaureate degrees, while a jurisdiction like the Netherlands, with a population about $25 \%$ greater than Ontario, has only 13 universities, and a higher rate of baccalaureate degree attainment than Ontario. Given the present capacity of Ontario universities, the most useful step toward adopting the European Model would be to make college baccalaureate programs more available to those students who are unlikely to attend a university. The most practical and efficient way of doing that would be to allow colleges to convert their three-year baccalaureate degree programs, as was recommended by the Commission on Postsecondary Education 44 years ago. 


\section{Notes}

1. The author served a term on the PEQAB right after it was established. The comments here are based on recent documents including the current PEQAB's Handbook for Colleges (Postsecondary Education Quality Assessment Board, 2014), rather than on recollections from the author's experience as a member of the board.

2. International comparative data on educational attainment are not available at the subnational level. This observation is based upon comparison of Canada with other OECD countries (OECD, 2013) and comparison of Ontario's educational attainment profile with that of Canada's (Norrie \& Lin, 2009). In 2011, Canada ranked first in the proportion of the population whose highest level of education was a college credential, with a rate of $25 \%$ compared to the OECD average of $10 \%$ (OECD, 2013). However, with $31 \%$ of its population aged $25-34$ with at least a baccalaureate degree, Canada was tied for $15^{\text {th }}$ among OECD countries. That was well below the rate for the two countries in which the applied sector accounts for the highest proportion of baccalaureate degrees, the Netherlands and Finland. Norrie and Lin showed that Ontario's rates for attainment of both a college credential and a baccalaureate degree were slightly higher than the Canadian average, but not sufficiently higher to suggest that Ontario's international profile would be substantially different from Canada's.

\section{References}

ACAATO. (1998). Leading economic development across Ontario: Achievements and opportunities. Toronto, ON. Retrieved from http://files.eric.ed.gov/fulltext/ED460716.pdf

ACAATO. (2005). Student mobility within Ontario's postsecondary sector. Toronto, ON. Retrieved from http://oncat.ca/files_docs/content/pdf/en/oncat_research_ reports/oncat_research_reports_13.pdf

Baker, D. N. (2002). On postsecondary quality assurance in Ontario: Introduction of Postsecondary Education Quality Assessment Board, 2001-02. A presentation at the Fourth International Conference on Assessing Quality in Higher Education, University of Vienna, Austria, July 24, 2002.

Bragg, D.D. (2002). Contemporary vocational models and programs: What the research tells us. New Directions for Community Colleges, 117, 25-34.

Brint, S., \& Karabel, J. (1989). The diverted dream: Community colleges and the promise of educational opportunity in America, 1900-1985. New York, NY: Oxford University Press.

Campbell, G. (1975). Some comments on reports of postsecondary commissions in relation to community colleges in Canada. Canadian Journal of Higher Education, 5(3), $55^{-68 .}$

Centre for Higher Education Policy Research (CHEPS). (2007). Higher education in the Netherlands: Country report. Enschede, Netherlands: University of Twente.

Clark, I. D., Moran, G., Skolnik, M.L., \& Trick, D. (2009). Academic transformation: The forces reshaping higher education in Ontario. Kingston, ON: McGill-Queen's University Press. 
Colleges Ontario. (2009). A new vision for higher education in Ontario. Toronto, ON. Retrieved from http://www.collegesontario.org/policy-positions/position-papers/newvision-for-higher-education.pdf

Colleges Ontario. (2012). Empowering Ontario: Transforming higher education in the $21^{\text {st }}$ Century. Toronto, ON. Retrieved from http://www.collegesontario.org/policypositions/position-papers/Empowering\%20Ontario\%20(2).pdf

Colleges Ontario. (2013). Reaching new heights: Differentiation and transformation in higher education. Toronto, ON. Retrieved from http://www.collegesontario.org/policypositions/position-papers/Reaching_New_Heights_Response_to_Differentiation_ Paper.pdf

Commission on Postsecondary Education in Ontario. (1972). The learning society. D.T. Wright, chairman. Toronto, ON: Ministry of Government Services.

Council of Ontario Universities. (2014). Enrolment: Summary of enrolments in Ontario universities 2003-04 to 2012-13 [Table 1]. Retrieved from http://cou.on.ca/ statistics/multi-year-data/enrolment

Council of Regents for the Colleges of Applied Arts and Technology of Ontario. (1990). Vision 200o: Quality and opportunity. Toronto, ON: Ministry of Training, Colleges and Universities.

Crow, S. D., Marsden, L., \& Rubidge, N. (2011). Report of an evaluation of the Postsecondary Education Quality Assessment Board in Ontario, Canada. Toronto, ON: Postsecondary Education Quality Assessment Board. Retrieved from http://www.peqab. ca/Publications/externalreview.pdf

Cunningham, D. (2000, October 19). Statement to the legislature by the Hon. Diane Cunningham, Minister of Training, Colleges and Universities, Introduction of the Ministry of Training, Colleges and Universities Statute Law Amendment Act, 2000.

Davis, W. G. (1965, May 21). Statement by the minister in the legislature. In Basic Documents: Colleges of Applied Arts and Technology. Toronto, ON: Department of Education (Reprinted June 1966), 5-16.

Doern, B. (2008). "Polytechnics" in higher education systems: A comparative review and policy implications for Ontario. Toronto, ON: Higher Education Quality Council of Ontario.

Fleming, R., \& Lee, G. R. (2009). Canada: What's in a title? In N. Garrod \& B. Macfarlane (Eds.), Challenging boundaries: Managing the integration of postsecondary education (pp. 93-110). New York, NY: Routledge.

Government of Alberta. (1998, October 2). Applied degrees to continue in postsecondary system: New proposals invited. Retrieved from http://www.gov.ab.ca/pab/ acn/199810/6828.html.

Hicks, M., Weingarten, H. P., Jonker, L., \& Shuping, L. (2013). The diversity of Ontario's colleges: A data set to inform the differentiation discussion. Toronto, ON: Higher Education Quality Council of Ontario/Queen's Printer for Ontario. Retrieved from http://www.heqco.ca/SiteCollectionDocuments/College_Differentiation_Report.pdf 
Higher Education Authority of Ireland. (2013). Higher education: Key facts and figures 2011/12. Retrieved from http://www.hea.ie/sites/default/files/keyfactsfigures1112_o.pdf

Higher Education Strategy Associates. (2012). Changing times, changing places: The global evolution of the bachelor's degree and the implications for Ontario. Toronto, ON: Higher Education Quality Council of Ontario.

Humber College. (2015). Advance your education-Transfer options. Retrieved from http://www.humber.ca/transferoptions/transfer_agreements/Business_Administration

Huys, I., Debackere, K., \& De Kock, L. (2009). Higher education in the Flemish community of Belgium, the French community of Belgium, Luxembourg and the Netherlands. Expertisecentrum O\&O Monitoring van de Vlaamise Gemeenschap, in collaboration with the Flemish Ministry of Education and Training. Retrieved from http:// www.ond.vlaanderen.be/hogeronderwijs/bologna/conference/documents/BENELUX_ HE.pdf

Huisman, J. (2008). Shifting boundaries in higher education: Dutch hogescholen on the move. In In J. S. Taylor, J. B. Ferreira, M. D. L. Machado, \& R. Santiago (Eds.), Nonuniversity higher education in Europe (pp. 147-168). Dordrecht, Netherlands: Springer.

Jones, G. A. (2004). Ontario higher education reform, 1995-2003: From modest modifications to policy reform. Canadian Journal of Higher Education, 34(3), 39-54.

Jones, G. A., \& Skolnik, M. L. (2009). Degrees of opportunity: Broadening student access by increasing institutional differentiation in Ontario higher education. Toronto, ON: Higher Education Quality Council of Ontario.

Karandjeff, K., \& Schiorring, E. (2011). Career and technical education (CTE) transfer research project: Improving transfer pathways for California college students in CTE programs. Journal of Applied Research in the Community College, 18(2), 42-51.

Kerr, A., McCloy, U., \& Shuping, L. (2010). Forging pathways: Students who transfer between Ontario colleges and universities. Toronto, ON: Higher Education Quality Council of Ontario.

Klumpp, M., de Boer, H., \& Vossensteyn, H. (2014). Comparing national policies on institutional profiling in Germany and the Netherlands. Comparative Education, 5O(2), 156-176.

Klumpp, M., \& Teichler, U. (2008). German fachhochschulen: Toward the end of a success story? In J. S. Taylor, J. B. Ferreira, M. D. L. Machado, \& R. Santiago (Eds.), Nonuniversity higher education in Europe (pp. 99-122). Dordrecht, Netherlands: Springer.

Laden, B.V. (2005). The new ABDs: Applied baccalaureate degrees in Ontario. In D.L. Floyd, M.L. Skolnik, and K.P. Walker (Eds.), The community college baccalaureate: Emerging trends and policy issues (pp. 153-178). Sterling, VA: Stylus Publishing, LLC.

Lewington, J. (1992, 29 January). In a class by themselves. The Globe and Mail, p. A4.

McFayden, C. (1989). Consultations on college-university linkages. Toronto. ON: Council of Regents for the Colleges of Applied Arts and Technology. 
Ministry of Education and Culture, Finland. (2009). Higher education institutions 2009: Universities and polytechnics as implementers of higher education policy. Retrieved from http://www.minedu.fi/export/sites/default/OPM/Julkaisut/2009/ liitteet/opm51.pdf?lang=fi

Netherlands Association of VET Colleges. (2014). Dutch vocational education and training and adult education. Retrieved from http://www.mboraad.nl/?page/530112/ About+us.aspx

Norrie, K., \& Lin, S. (2009). Postsecondary education attainment and participation in Ontario. Toronto, ON: Higher Education Quality Council of Ontario.

OECD. (1971). Towards new structures of postsecondary education. Paris, France.

OECD. (1973). Short-cycle higher education: A search for identity. Paris, France.

OECD. (2005). Education policy analysis. Paris, France: Publication 16/11/2006.

OECD: (2013). Education at a glance 2013: OECD indicators. OECD Publishing. http://dx.doi.org/10.1787/eag-2013-en Retreived from http://www.oecd.org/edu/ eag2013\%20(eng)--FINAL\%2020\%20June\%202013.pdf

ONCAT. (2014). ONCAT 2013-14 Annual report. Toronto, ON. Retrieved from http:// www.oncat.ca/files_docs/content/pdf/en/2013-14-ONCAT-AnnualReport_ENG.pdf

Ontario Confederation of University Faculty Associations. (2000). Brief to the standing committee on general government, Bill 132.

Ontario Ministry of Training, Colleges and Universities. (2003, February 10). Backgrounder: Institutes of technology and advanced learning.

Ontario Ministry of Training, Colleges and Universities. (2014a). College enrolment: Headcount by college and level of study, [20]12-[20]13.. Retrieved from https://www. ontario.ca/education-and-training/college-enrolments

Ontario Ministry of Training, Colleges and Universities. (2014b). College enrolment: Headcount by university and year of study, fall [20]12-[20]13. Retrieved from https:// www.ontario.ca/education-and-training/university-enrolment-o

Panacci, A. (2014). Baccalaureate degrees at Ontario colleges: Issues and implications. College Quarterly, 17(1). Retrieved from http://www.collegequarterly.ca/2014-vol17numo1-winter/panacci.html

Portal Belgium Government. (2015). A statistical overview of the Belgian population. Retrieved from http://www.belgium.be/en/about_belgium/country/Population/

Postsecondary Education Quality Assessment Board. (2014). Handbook for Ontario colleges: Applying for Consent under the Post-secondary Education Choice and Excellence Act, 2000. Retrieved from http://www.peqab.ca/Publications/HNDBKCAAT2014.pdf

R. A. Malatest \& Associates Ltd. (2010). Evaluation of degrees in applied areas of study: Final report. Toronto, ON: Ministry of Traiing, Colleges and Universities.

Royce, D. (1998). University system coordination and planning in Ontario, 19451996 (Unpublished doctoral dissertation). University of Toronto, Toronto, ON. 
Russell, A. B. (2013). Update on the community college baccalaureate. In N. Remington \& R. Remington (Eds.), Alternative pathways to the baccalaureate (pp. 67-84). Sterling, VA: Stylus.

Ruud, C. M., Bragg, D. D., \& Townsend, B. K. (2010). The applied baccalaureate degree: The right time and place. Community College Journal of Research and Practice, 34(1), 136-152.

Skolnik, M. L. (1989). How Ontario's college system might respond to pressures for the provision of more advanced training. Toronto, ON: Ontario Council of Regents for the Colleges of Applied Arts and Technology.

Skolnik, M. L. (2009). Theorizing about the emergence of the community college baccalaureate. Community College Journal of Research and Practice, 33(2), 125-150.

Skolnik, M. L. (2010). A look back at the decision on the transfer function at the founding of Ontario's colleges of applied arts and technology. Canadian Journal of Higher Education, 4O(2), 1-17.

Skolnik, M. L. (2013). Reflections on the nature and status of the applied baccalaureate degree. In N. Remington \& R. Remington (Eds.), Alternative pathways to the baccalaureate (pp. 128-147). Sterling, VA: Stylus.

Skolnik, M. L. (2016). How do quality assurance systems accommodate the differences between academic and applied higher education? Higher Education, 71(3), 361-378.

Slantcheva-Durst, S. (2010). Redefining short-cycle higher education across Europe: The challenges of Bologna. Community College Review, 38(2), 111-32.

Standing Committee on General Government. (2000, November 22). Committee transcript: Bill 132, Ministry of Training, Colleges and Universities Statute Law Amendment Act, 2000. Retrieved from http://www.ontla.on.ca/committee-proceedings/transcripts/ files_html/2000-11-22_Go35.htm\#P141_47560

Stoll, P. (1993). A question of transfer: An historical review of the Ontario colleges' mandate (Unpublished Master of Education Thesis). Brock University, St. Catharines, ON.

St. Petersburg College. (2015a). Bachelor's degrees. Retrieved from http://www. spcollege.edu/bachelordegrees/

St. Petersburg College. (2015b). Bachelor's degrees at UPC. Retrieved from http:// www.spcollege.edu/UPC-Bachelors/

Taylor, J. S., Ferreira, J. B., Machado, M. D. L., \& Santiago, R. (2008). Non-university higher education in Europe. Dordrecht, Netherlands: Springer.

Townsend, B. K. (2002). Terminal students do transfer. Paper presented at the annual meeting of the American Association of Community Colleges, Seattle, WA, April 23, 2002.

Townsend, B. K. (2004). The upside down degree. Paper presented at the annual meeting of the Association for the Study of Higher Education, Kansas City, MO, November 4-7, 2004. 
Townsend, B. K., Bragg, D. D., \& Rudd, C. M. (2008). The adult learner and the applied baccalaureate: National and state-by-state inventory. Office of Community College Research and Leadership, University of Illinois at Urbana-Champaign. Retrieved from http://occrl.illinois.edu/files/Projects/lumina/Report/AppBaccInventory.pdf

Townsend, B. K., Bragg, D. D. \& Ruud, C. M. (2009). Development of the applied baccalaureate, Community College Journal of Research and Practice, 33(9), 586-705.

Trick, D. (2013). College-to-university transfer arrangements and undergraduate education: Ontario in a national and international context. Toronto, ON: Higher Education Quality Council of Ontario.

Trow, M. (1973). Problems in the transition from elite to mass higher education. Berkeley, CA: Carnegie Commission on Higher Education Reprint.

Välimaa, J. \& Neuvonen-Rauhala, M. (2008). Polytechnics in Finnish higher education. In J. S. Taylor, J. B. Ferreira, M. D. L. Machado, \& R. Santiago (Eds.), Non-university higher education in Europe (pp. 77-98). Dordrecht, Netherlands: Springer.

Walker, K. P., \& Floyd, D. L. (2005). Applied and workforce baccalaureates. In D. L. Floyd, M. L. Skolnik \& K. P. Walker (Eds.), The community college baccalaureate: Emerging trends and policy issues (pp. 95-102). Sterling, VA: Stylus.

Weinrib, J. \& Jones, G. A. (2014). Largely a matter of degrees: Quality assurance and Canadian universities. Policy \& Society: An Interdisciplinary Journal of Policy Research, 33(3), 225-236.

Witte, J., van der Wende, M., \& Huisman, J. (2008). Blurring boundaries: How the Bologna process changes the relationship between university and non-university higher education in Germany, the Netherlands and France. Studies in Higher Education, 33(3), 217-231.

\section{Contact Information}

Michael L. Skolnik

Ontario Institute for Studies in Education

University of Toronto

mike.skolnik@utoronto.ca

Michael Skolnik is a professor emeritus in the Ontario Institute for Studies in Education of the University of Toronto, where he held the William G. Davis Chair in Community College Leadership and directed the PhD program in Community College Leadership. His current research focuses on the organization of higher education, quality assurance, and qualifications frameworks. In 2011, he was the recipient of the CJHE Sheffield Award for his article, "A Look Back at the Decision on the Transfer Function at the Founding of Ontario's Colleges of Applied Arts and Technology.” 